\title{
Clarifying the degree and type of public good collective action problem posed by natural resource management challenges
}

\author{
Rebecca M. Niemiec $^{1}$, Sarah McCaffrey ${ }^{2}$ and Megan S. Jones ${ }^{1}$
}

\begin{abstract}
Increasingly, scholars have sought to understand the role of collective action across property boundaries to address natural resource management challenges. Although the growing focus on collective action for natural resource management has led to many new and potentially useful insights for governance and outreach, we suggest that researchers and practitioners may benefit from taking a step back to think about the degree and type of collective action that is needed for each particular social-ecological context. We use the examples of invasive species management, fire management, and habitat conservation to argue that categorizing certain natural resource management challenges by the degree and type of public good collective action problem (i.e., continuous and step level) they create can provide insight into effective policy and management solutions for each problem. In so doing, we build on experimental psychology and economics research that suggests that outreach and governance solutions that work for one type of public good collective action problem may be less effective for addressing another type of problem that does not require collective action. We conclude by arguing for more studies examining: (1) how aspects of the social and ecological context determine the degree and type of public good collective action problem posed by natural resource management challenges, and (2) how the drivers of land manager decision making and the resulting effective governance solutions vary by the type and degree of public good collective action problem.
\end{abstract}

Key Words: collective action; conservation; fire; habitat; invasive species; private lands; public good

\section{INTRODUCTION}

For many natural resource management challenges, the effectiveness of management efforts on one property may be influenced by actions taken on neighboring properties, making cooperation among land managers across properties often essential for achieving management goals (Epanchin-Niell et al. 2010, Graham and Rogers 2017, Warziniack et al. 2018). As recognition of the cross-boundary nature of many natural resource management challenges has grown, scholars and land managers have increasingly focused attention on understanding how to foster land manager collective action across property boundaries (Fischer and Charnley 2012, Canadas et al. 2016, Niemiec et al. 2016, Graham and Rogers 2017, Ma et al. 2018, Fischer et al. 2019). Collective action has been defined in numerous ways; here, we draw on the following definition: "collective action requires the involvement of a group of people, it requires a shared interest within the group, and it involves some kind of common action that works in pursuit of that shared interest" (Meinzen-Dick et al. 2004:200, emphasis in original). Governance approaches that motivate community-based collective action (e.g., collaborative watershed partnerships [Cooke et al. 2012] or local landholder groups [e.g., Landcare groups in Australia; McKiernan 2018]) can facilitate the establishment of new norms and monitoring and sanctioning systems among community members, which could encourage sustained land manager engagement in the desired natural resource management behavior (Ostrom 1990). Furthermore, governance approaches focused on facilitating collective action among land managers may avoid the reactance caused by topdown regulations (i.e., laws and fines), which private landowners often believe are inflexible, inefficient, onerous, and undermine private property rights (Doremus 2003, Cooke et al. 2012).
In relation to natural resource management, much of the scholarly work to date has focused on common-pool resource (CPR) collective action problems (Ostrom 1990, Cox et al. 2010) in which a finite resource is available to all, consumption by one individual reduces the availability of that resource for others (it is a "rival" good), and restraints on consumption are typically (but not always) required (Graham et al. 2019). Fewer studies have focused on understanding public good collective action problems in which the resource is generally available to all for consumption, but one person using the resource does not reduce its availability for others (i.e., it is "nonrival"; Kollock 1998). Public good collective action problems typically require contributions in the form of effort, time, or resources to ensure that the public good is provided (Graham et al. 2019). Although many natural resource management challenges do not fit perfectly within the public good or CPR distinction (e.g., with very limited space, even fresh air becomes a CPR, and the governance institutions to manage CPR can often become public goods themselves), distinguishing between public good and CPR problems can nonetheless be useful because the two types of collective action problems can pose different decision-making contexts, and findings from CPR problems may not always apply to public good problems (Cox et al. 2010, Bagavathiannan et al. 2019, Graham et al. 2019).

Because many natural resource management challenges can resemble public good more than CPR problems (Bagavathiannan et al. 2019, Graham et al. 2019), there is a need for more consideration of how insights from the existing work specific to public good collective action problems might inform management across property boundaries. Here, we consider three natural resource management private property challenges that are often assumed to pose a public good collective action problem: invasive species management, fire management, and habitat conservation.

${ }^{1}$ Human Dimensions of Natural Resources Department, Colorado State University, ${ }^{2}$ USDA Forest Service, 240 West Prospect Road, Fort Collins, CO 80526 USA 
A growing body of literature has begun to examine the factors influencing land managers' willingness to engage in collective action with others to address these problems (Fischer and Charnley 2012, Canadas et al. 2016, Niemiec et al. 2016, Graham and Rogers 2017, Ma et al. 2018, Fischer et al. 2019). Reducing invasive species populations across property boundaries can pose a public good collective action problem because the communitylevel benefits of invasive species control (e.g., reduced social and economic impacts and enhanced biodiversity outcomes) can be enjoyed by anyone without detracting from others' enjoyment (Graham et al. 2019). Similarly, homeowner contributions to reduced wildfire risk and enhanced habitat connectivity can be classified as public good scenarios because anyone can enjoy the collective benefits that arise from reduced wildfire risk or increased biodiversity without detracting from others' enjoyment of these benefits (Bagavathiannan et al 2019, Graham et al. 2019).

Although the growing focus on collective action for diverse natural resource management challenges on private property has led to many new and potentially useful insights for governance and outreach, we suggest that researchers and practitioners may benefit from taking a step back to think about when and what kind of collective action is actually needed for a given socialecological context. We argue that for many natural resource management challenges, the degree and type of public good collective action problem that is created may vary by the socialecological context and management objective. We also suggest that there may be different drivers of decision making, and thus, optimal governance and outreach strategies, for different types and degrees of public good problems. Our goal is not to conduct a systematic review of the environmental social science literature on collective action. Rather, our objective is to draw from field and laboratory research on collective action problems to develop a more nuanced understanding about the degree and type of public good collective action problem posed by different natural resource management challenges across private lands, the differential drivers of decision making under different contexts, and what these insights might mean for managers as well as future research needs.

\section{OBJECTIVES AND APPROACH}

We bring together two sources of literature: (1) social and ecological studies that lend insight into the type and degree of public good collective action problem posed by invasive species management, fire management, and habitat provisioning on private lands; and (2) experimental psychology and economics studies, which explore different types of public good collective action scenarios and how optimal outreach and governance solutions may vary across different scenarios using stimulated social dilemma "games". We also draw from preliminary environmental social science research examining how the drivers of landowner decision making may vary by the degree of collective action in which an individual engages.

We focus our discussion of collective action on two scales of management objectives: property level and community level. We define property-level management objectives as outcomes that land managers seek to achieve on their properties through natural resource management. We define community- or landscape-level management objectives as outcomes that natural resource managers seek to achieve across a larger area that encompasses many different land managers, ranging from the neighborhood to the landscape scale. Although public lands are critical to consider, our focus here is primarily on private landowners for which the diversity of parcel sizes, motivations, and decisionmaking contexts raise significant questions about the degree and type of collective action needed.

In the remainder of this paper, we first draw from invasive species management studies to investigate the assumption that certain natural resource management challenges pose a collective action problem because of the cross-boundary nature of the threat. In particular, we argue that the degree of collective action that is needed varies by the social-ecological context and management objective. Second, we discuss how different social-ecological contexts can lead to different types of public good collective action problems, which can be categorized using existing typologies from experimental psychology and economics research. Third, we discuss evidence from laboratory and field research that suggests these different types of public good collective action problems, as well as noncollective action problems, may create different decision-making contexts and may thus have different potential governance and outreach solutions. Finally, we discuss how these public good collective action typologies may apply to other natural resource management challenges such as habitat provisioning for biodiversity conservation and wildfire mitigation strategies.

\section{DIFFERENT DEGREES OF PUBLIC GOOD COLLECTIVE ACTION PROBLEMS: THE CASE OF INVASIVE SPECIES}

Studies of collective action for natural resource management challenges suggest that the cross-boundary nature of these threats can mean that, in many situations, achieving both communityand property-level outcomes poses a public good collective action problem. With regard to property-level management outcomes, it is often assumed that land managers' individual actions on their property will be ineffective if neighboring managers in a community are not also taking action because of spillover between land properties (Epanchin-Niell et al. 2010, Fenichel et al 2014, Warziniack et al. 2018). At the community or landscape scale, it is often assumed that objectives throughout an area cannot be achieved if most or all property managers are not taking action (Fischer and Charnley 2012, Yung et al. 2015, Niemiec et al. 2017). Although these assumptions may be true in certain management scenarios, the social and ecological contexts often shape both the degree to which individual's actions on their property are affected by others' participation (i.e., the degree of spillover between properties) and the degree to which communitylevel outcomes are affected by everyone's participation.

These dynamics can be illustrated via the example of invasive species management. Although achieving community-level invasive species management objectives across multiple property boundaries typically requires some degree of collective action (Epanchin-Niell et al. 2010, Graham 2013, Graham and Rogers 2017), studies suggest that the extent of collective action needed may vary based on characteristics of the species (e.g., size, reproduction rate, mobility) and of the land properties (i.e., size, configuration of properties). For instance, Glen et al. (2017) found that not all landholders needed to participate in coordinated invasive species control efforts in order to achieve widespread 
reductions in invasive predator (i.e., feral cats Felis catus, stoats Mustela erminea, and ferrets $M$. furo) populations in the Hawke's Bay region of New Zealand. They found that participation by small-scale landholders ( $\leq 25 \mathrm{ha}$ ) was not necessary to achieve conservation outcomes, and even nonparticipation by certain large properties ( $>800$ ha) could be mitigated if adjacent properties compensated by placing additional traps on their boundaries. Glen et al. (2017) therefore concluded that collective action among all properties was not necessary to achieve community-level outcomes and make each individual's efforts worthwhile; rather, only a portion of land managers needed to be involved.

With regard to property-level management outcomes, studies of the ecology of different types of invasive species suggest the degree of collective action needed to reduce property-level impacts may also vary based on social and ecological characteristics. For example, in Hawaii, different levels of collective action are needed to reduce property-level social and economic impacts from two different invasive species: albizia (Falcataria moluccana) and little fire ant (Wasmannia auropunctata). Albizia is an invasive tree that can fall on homes in high winds, can have a canopy that extends across 0.5 ha, and has seeds that can spread $>200 \mathrm{~m}$ (Hughes et al. 2013). Propagule pressure means that the effectiveness of efforts to reduce the negative effects of albizia on an individual property are strongly influenced by others' control efforts in the surrounding neighborhood. The albizia's size and broad canopy also mean that an albizia on a neighboring property could fall on someone else's property, threatening their safety. Furthermore, albizia on one property may fall on powerlines and roads, causing negative impacts for all other residents in a community. Thus, in areas with small property sizes, it is often impossible for a land manager to reduce negative impacts from albizia without recruiting community members to take action (Niemiec et al. 2016).

In contrast, property-level management of the invasive little fire ant, which causes painful stings that blind domestic pets, requires limited or no collective action because of its small size and limited mobility. Little fire ant will travel approximately $6 \mathrm{~m}$ from its parent nest to forage, although it can spread by hitchhiking on material, such as wood, that is moved by people (Vanderwoude et al. 2010). Given little fire ant's limited mobility, an infestation can generally be fully eradicated or contained within a larger property using repeated baiting and barrier treatments. Vanderwoude et al. (2010), for example, report on a 0.5-ha little fire ant infestation on Maui, Hawaii that was successfully contained within a 2 -ha property. Overall, preventing negative property-level impacts from little fire ant usually does not require getting everyone in the community involved, except in the context of moving wood or other materials from others' properties. However, when properties are small enough for little fire ant to move between properties, management is more effective if multiple neighbors work together on control efforts (Niemiec et al. 2018).

This evidence suggests that the degree of collective action needed for effective invasive species management at a property or community level will vary based on the mobility and size of the species as well as the size, proximity, and configuration of individual parcels. It suggests, further, that the common assumption that collective action is needed among all community members to improve natural resource management may be overly simplistic. Rather, the scale of different management goals (i.e., property and community level) and the local social and ecological conditions may necessitate different levels of collective action.

\section{DIFFERENT TYPES OF PUBLIC GOOD COLLECTIVE ACTION PROBLEMS: A TYPOLOGY FROM EXPERIMENTAL STUDIES}

A first step in determining the type of public good collective action problem is determining whether the specific context actually requires collective action. When the desired management goal is to achieve property-level outcomes, many natural resource challenges can be noncollective action problems, depending on the degree of spillover between properties. Noncollective action problems occur when property managers: (1) can achieve desired outcomes (such as reduced effects of invasive species or increased abundance and diversity of native species) on their properties, and (2) the effectiveness of their efforts is not influenced by (and does not influence) neighboring land managers. For instance, if the desired management outcome is to reduce little fire ant populations on a property, and property sizes are large enough that the infestation is contained within the property, this outcome may be achieved without collective action.

When a managers' ability to achieve a desired management outcome on their property is affected by (or affects) neighboring land managers' actions or objectives, achieving property-level management outcomes poses a collective action problem. Furthermore, a collective action problem is created when a manager has a community-level management objective that requires the actions of multiple land managers. As described earlier, if the resource is rival, i.e., one person's consumption reduces availability to all, a CPR problem is created. If the resource is nonrival, i.e., one's consumption or enjoyment of the good does not influence others' enjoyment or consumption, a public good problem is created: this latter situation is our current focus (see Cox et al. 2010 for a review of CPR problems).

The notion that different scales of natural resource management objectives amid different social-ecological contexts may require different degrees of collective action relates closely to social science theory, which distinguishes between different categories of public good collective action problems (Kolluck 1998, Abele et al. 2010). Public good problems can be categorized into continuous and step-level problems based on the type and degree of individual contributions necessary to achieve the desired public good (Abele et al. 2010). This distinction has typically been made in the experimental psychology and economics literature, which investigate the resolution of collective action problems through experimental social dilemma games typically conducted in a laboratory setting, but has rarely been applied to understand natural resource management challenges. In a literature search that identified $>80$ experimental studies, Abele et al. (2010) found that approximately half examined continuous public good problems, whereas half examined step-level problems.

\section{Continuous public good collective action problems}

Continuous public good collective action problems are defined as scenarios "in which a public benefit increases as a continuous function (usually linear) of individual contributions" (Abele et 
al. 2010:385). For continuous public good collective action problems, the effect of an individual's contribution to the public good is not influenced by how many others also contribute. In a lab experiment setting, continuous public good problems can be simulated through a game in which every player is given an endowment. Players can choose to contribute a portion of the endowment to the "public account" or keep the endowment for themselves. At the end of the game, contributions to the public account are then multiplied by some factor and distributed equally back among the players. In the continuous public good scenario, the multiplicative factor is set so that individuals are always better off (in terms of the endowment they receive at the end) if they "free-ride", or refrain from contributing to the public account, regardless of how many others contribute. However, the fewer people that contribute, the worse off the group is.

Reducing populations of little fire ant at a community level is an example of a continuous collective action problem because achieving community-level reductions in populations requires that many land managers control little fire ant on their own properties. However, because little fire ant has limited mobility, each unit of management effort contributes relatively equally toward improved community-level outcomes regardless of how many other land managers participate.

\section{Step-level public good collective action problems}

Step-level public good collective action problems require that individuals contribute a certain threshold amount of effort or resources. Although contributions up to the threshold are critical for the provisioning of the public good, once the threshold is reached, additional contributions make much less of an impact (Abele et al. 2010). In a lab experiment setting, step-level public good problems can be simulated by a similar situation as described above for continuous problems: individuals have the option of contributing to a public account, which then gets multiplied and distributed back. However, instead of players automatically receiving a portion of the public account at the end of the game, players only receive a portion if total contributions reach the threshold (also referred to as the "provision point"). After reaching this point, excess contributions may make some or no difference to the overall public account. In these experiments, the multiplicative factor is often set so that if an individual's contribution allows the group to reach the provision point, the individual is better off contributing than not (because of the portion of the collective that will be distributed back among the players).

Managing invasive predators at a community scale in the New Zealand case study (Glen et al. 2017) is an example of a step-level problem because it required a certain threshold number of large private landholders to take action. Once that threshold or provision point was reached, others' contributions (particularly the small property land managers) made relatively little difference to the desired reduction in invasive predator populations.

To understand the problem created by a particular natural resource management challenge on private lands, we therefore suggest that managers and researchers first assess whether the social-ecological context and management objective create a noncollective action problem or a collective action problem. If a collective action problem is created, managers and researchers can assess whether the resource is rival or nonrival to determine whether a CPR or public good problem is created. If the natural resource management issue creates a public good problem, managers and researchers may then determine whether there is a provision point to distinguish between step-level and continuous public good problems, each of which may require different governance and outreach solutions.

\section{DIFFERENT DEGREES AND TYPES OF PUBLIC GOOD COLLECTIVE ACTION PROBLEMS MAY HAVE DIFFERENT GOVERNANCE AND OUTREACH SOLUTIONS}

Clarifying the type of natural resource management collective action problem one is (or, perhaps, is not) dealing with is important because studies suggest that there may be different drivers of decision making for noncollective action problems compared to collective action problems, for public good vs. CPR problems, and for continuous vs. step-level public good problems. We next summarize how different decision-making contexts for different types of problems may lead to different optimal outreach and governance solutions.

Noncollective action problems vs. collective action problems

Preliminary field-based research suggests that the barriers and motivations influencing environmental behavior may vary by the degree to which the behavior involves engaging collectively with others (Amel et al. 2017). Studies suggest that people's willingness to engage in property-level action, regardless of collective action considerations to address natural resource management challenges, is influenced by a range of factors such as knowledge, risk perceptions, environmental attitudes and values, demographics, property size, self-efficacy, response efficacy, place attachment, and trust in agencies and organizations conducting outreach (Prokopy et al. 2008, Aslan et al. 2009, McCaffrey 2015, Niemiec et al. 2018).

In relation to collective action for a natural resource management challenge, field studies have identified a number of additional influencing factors, including social identity, social interactions, and beliefs about others in one's community, including beliefs about whether others care about the issue and how they will respond to collective efforts (Lubell et al. 2007, Brenkert-Smith 2010, Bamberg et al. 2015, Marshall et al. 2016, Amel et al. 2017). Niemiec et al. (2018) found that fear of social sanctions from neighbors, as well as the frequency of interaction with others in the community, were significant predictors of residents' engagement in collective action with neighbors for invasive species control but not of their individual action on their property. Other research suggests that fear of being judged negatively by others and the belief that others do not care about the issue may be particularly salient barriers to engaging in collective action for climate change (Geiger and Swim 2016). These preliminary fieldbased findings suggest that there may be unique barriers and motivations to engaging in collective action compared to more individualized action (Amel et al. 2017). Outreach that changes beliefs about others in one's community (e.g., the programs summarized in Geiger and Swim 2016, Fairbrother et al. 2013, and Niemiec et al. 2019) may be particularly important for motivating behaviors that require high levels of collective action.

\section{Common-pool resource vs. public good problems}

Studies also suggest that public good and CPR problems pose different decision-making contexts with potential implications for outreach and governance (Cox et al. 2010; see Bagavathiannan et 
al. 2019 and Graham et al. 2019 for more in-depth discussions of these differences). For instance, Bagavathiannan et al. (2019) suggest that not all of the eight core design principles Ostrom (1990) identified for CPR governance may be relevant to public good collective action problems. For example, they found that accessible, low-cost means for dispute resolution may be less important for addressing invasive weed management-related public good problems. They also suggest that, given the contribution requirement of public good problems, four additional conditions not identified in the CPR literature may be important for the effective management of public goods: "(1) having a clearly articulated shared goal and securing commitments from actors to contribute, (2) establishing good working relationships and shared values among contributors, (3) making individual contributions transparent, and (4) generating pooled resources to support weakest-link problems or address asymmetries in the public good" (Bagavathiannan et al. 2019:349). Existing literature therefore suggests that institutions and outreach programs addressing public good problems may be more effective if they facilitate these additional conditions, rather than solely applying the CPR design principles.

\section{Continuous vs. step-level public good problems}

Experimental lab-based research suggests that there also may be different drivers of decision making for continuous and step-level public good problems (Table 1), in large part because the provision point characteristic of step-level public good problems creates the need for coordination and a different pay-off structure for individuals seeking to maximize personal gains (Ledyard 1995, Abele et al. 2010). Building on research on game theory (Ledyard 1995), which initially operated on the assumption that individuals primarily focus on maximizing their personal endowment, Abele et al. (2010) argue that continuous games have one optimal solution (i.e., "Nash equilibrium"): contributing nothing will always maximize an individual's personal pay-off. In a step-level game, on the other hand, contributing up to the level of the provision point can also be an optimal individual solution, in addition to contributing nothing (Table 1, row 1). This situation may occur if an individual is certain that their contribution is essential to reach the provision point because that individual will then be guaranteed to receive a portion of the collective in return. Thus, whereas the optimal solution from the perspective of an individual trying to maximize personal gains is always to avoid contributing in continuous problems, in step-level problems, an optimal solution also might involve contributing to help reach the provision point (Ledyard 1995, Abele et al. 2010).

Abele et al. (2010) also argue that continuous and step-level collective action problems are fundamentally different because they vary in the degree to which individuals' actions are interdependent (see also Kelley and Thibaut's 1978 social interdependence theory), thereby introducing cooperation and coordination considerations into the decision process (Table 1, row 2). As described above, in lab experiments of continuous games, an individual is always incentivized to free-ride on others' contributions and has no personal incentive to cooperate with others because contributing to the group always costs them personally, and they can benefit from the group even if they do not contribute (Ledyard 1995). In contrast, the existence of a provision point in step-level public goods creates coordination problems: if players coordinate their contributions to ensure the provision point is reached, they can maximize their individual gains because they can receive a portion of the collective benefit (Ledyard 1995, Abele et al. 2010). Thus, cooperation may help maximize individual gains in step-level public goods games, but it will not maximize individual gains in continuous public goods games.

A growing body of experimental work has modified the parameters of the original public good game to approximate more real-world conditions (e.g., communication among individuals, varying group sizes) and to allow for goals other than maximizing personal endowment (Isaac et al. 1994, Kollock 1998). That work suggests that several factors could differentially influence collective action decisions in step-level and continuous public good scenarios (Table 1, rows 3-6). One important dynamic that was identified is the degree to which an individual values personal gain vs. collective outcomes (Table 1, row 3 ). With continuous collective action problems, the desire to maximize personal and joint outcomes are always at odds, given that an individual can always free-ride on others' contributions. Thus, how much an individual values collective over individual outcomes may be particularly important for predicting their willingness to contribute. Indeed, studies found that contributions to continuous public goods were consistently predicted by the degree to which individuals value collective outcomes over their own personal gain (Abele et al. 2010). Field studies find that environmental value orientations, a measure of how much individuals value a public good, can influence environmental beliefs, leading to greater contributions to continuous natural resource management collective action problems such as energy conservation (Fornara et al. 2016). In contrast, Abele et al. (2010) found that the degree to which individuals value collective outcomes was less relevant for step-level collective action problems, where personal gain and collective gain are sometimes compatible.

Three other factors that have been found to influence individuals' differential responses to continuous vs. step-level public good collective action problems include group size, the level and type of communication among group members, and fear that others will not contribute (Kollock 1998, Abele et al. 2010; Table 1, rows 4-6). For continuous collective action problems, lab experiments have found that actions on behalf of the collective generally increased with group size, possibly because individuals were motivated by seeing a large number of others contributing to the collective (e.g., Isaac et al. 1994). This effect has been replicated in field experiments; for example, showing how the majority of others are contributing to a continuous collective action problem such as water conservation can enhance contributions (Goldstein et al. 2008). In lab-based experiments, increasing communication has sometimes been found to reduce contributions for continuous public good problems when the communication is not face-toface, and pledges to contribute are nonbinding. This result is because communication may lead to deceptive promises to cooperate, which can create mistrust when these promises are not upheld (see review by Abele et al. 2010; S. Abele, G. Stasser, and C. Chartier, unpublished manuscript). Face-to-face communication, therefore, may be particularly important for continuous collective action problems because it can create a shared group identity, which can increase people's perceived obligation to the group (Abele et al. 2010). 
Table 1. A summary of how different factors may influence decision making for continuous vs. step-level public good scenarios and potential implications for governance. The table builds on the review of social dilemma laboratory-based experiments by Abele et al. (2010).

\begin{tabular}{|c|c|c|c|}
\hline Decision-making factor & $\begin{array}{l}\text { How decision-making factor applies to } \\
\text { continuous public goods }\end{array}$ & $\begin{array}{l}\text { How decision-making factor applies to } \\
\text { step-level public goods }\end{array}$ & $\begin{array}{l}\text { Implications for governance and } \\
\text { outreach }\end{array}$ \\
\hline $\begin{array}{l}\text { What is the optimal } \\
\text { solution for actors only } \\
\text { seeking to maximize their } \\
\text { own individual outcomes? }\end{array}$ & $\begin{array}{l}\text { Optimal solution is not contributing } \\
\text { because free-riding always maximizes } \\
\text { individual outcomes }\end{array}$ & $\begin{array}{l}\text { Optimal solution can be not } \\
\text { contributing or contributing to meet } \\
\text { provision point }\end{array}$ & $\begin{array}{l}\text { Mechanisms for aligning individuals' } \\
\text { personal interests with collective interests } \\
\text { may be particularly important for } \\
\text { continuous goods }\end{array}$ \\
\hline $\begin{array}{l}\text { How important are } \\
\text { interdependence and } \\
\text { coordination? }\end{array}$ & $\begin{array}{l}\text { Coordination is less crucial than for } \\
\text { step-level goods because outcomes from } \\
\text { different levels of individual } \\
\text { contributions are unaffected by what } \\
\text { others do }\end{array}$ & $\begin{array}{l}\text { Outcomes from different levels of } \\
\text { contributions are affected by what } \\
\text { others do; coordination of contributions } \\
\text { to meet the provision point can benefit } \\
\text { everyone }\end{array}$ & $\begin{array}{l}\text { Mechanisms for facilitating coordination } \\
\text { may be important for step-level goods }\end{array}$ \\
\hline $\begin{array}{l}\text { What is the effect of } \\
\text { valuing collective } \\
\text { outcomes? }\end{array}$ & $\begin{array}{l}\text { Maximizing individual and collective } \\
\text { outcomes is always at odds; placing } \\
\text { greater value on collective outcomes is } \\
\text { consistently linked with greater } \\
\text { willingness to contribute }\end{array}$ & $\begin{array}{l}\text { Placing greater value on collective } \\
\text { outcomes is not as consistently linked to } \\
\text { contributions because achieving } \\
\text { individual and collective outcomes may } \\
\text { be complementary }\end{array}$ & $\begin{array}{l}\text { Mechanisms for enhancing the perceived } \\
\text { value of the collective outcome may be } \\
\text { important for continuous goods }\end{array}$ \\
\hline $\begin{array}{l}\text { Is bigger or smaller group } \\
\text { size better? }\end{array}$ & $\begin{array}{l}\text { Contributions tend to increase with } \\
\text { increasing group size }\end{array}$ & $\begin{array}{l}\text { Contributions may decrease with larger } \\
\text { group size because, in larger groups, } \\
\text { individuals may no longer see their } \\
\text { contribution as critical for achieving the } \\
\text { provision point }\end{array}$ & $\begin{array}{l}\text { May be important for programs to } \\
\text { highlight large group size for continuous } \\
\text { goods and small group size for step-level } \\
\text { goods }\end{array}$ \\
\hline $\begin{array}{l}\text { How important is } \\
\text { communication between } \\
\text { actors? }\end{array}$ & $\begin{array}{l}\text { Communication that is not face-to-face } \\
\text { and commitments that are nonbinding } \\
\text { may lead to deceptive promises, which } \\
\text { can decrease contributions }\end{array}$ & $\begin{array}{l}\text { Any form of communication can } \\
\text { increase contributions because } \\
\text { communication can help with } \\
\text { coordination to achieve the provision } \\
\text { point, and interdependencies reinforce } \\
\text { the importance of commitments }\end{array}$ & $\begin{array}{l}\text { Mechanisms to facilitate communication } \\
\text { likely are crucial for both types of public } \\
\text { good problems, but for continuous } \\
\text { goods, such mechanisms should be face- } \\
\text { to-face and include binding pledges to } \\
\text { strengthen group identity and sense of } \\
\text { obligation }\end{array}$ \\
\hline $\begin{array}{l}\text { Does fear that others will } \\
\text { not contribute affect } \\
\text { contributions? }\end{array}$ & $\begin{array}{l}\text { Fear may be less important than for } \\
\text { step-level goods because the } \\
\text { effectiveness of one individual's efforts is } \\
\text { not influenced by others' efforts }\end{array}$ & $\begin{array}{l}\text { Fear that others will not contribute, and } \\
\text { that the provision point will not be } \\
\text { reached, can prevent action }\end{array}$ & $\begin{array}{l}\text { Programs addressing step-level goods } \\
\text { should specifically seek to assuage the } \\
\text { fear that others will not contribute }\end{array}$ \\
\hline
\end{tabular}

${ }^{\dagger}$ Continuous public goods have no provision point, and the effectiveness of actions is not influenced by others' contributions.

'Step-level public goods have a provision point, and the effectiveness of actions is influenced by others' contributions.

For step-level collective action problems, in contrast, lab-based experimental work by Kerr (1989) shows that contributions to the public good decrease with increasing group size, possibly because individuals are less likely to believe that their actions are essential to reaching the provision point (Table 1 , row 4). Studies also found that any form of communication is effective at increasing contributions to step-level problems because communication allows individuals within a group to make agreements on how to coordinate efforts to ensure that the provision point is reached (Abele et al. 2010; Table 1, row 5). Studies found that individuals often then felt personally obligated to uphold these agreements (Kerr et al. 1997), potentially because of the interdependencies inherent in step-level public good scenarios. Finally, lab experiments and field studies suggest that fear that others will not contribute enough effort or resources to achieve the provision point can prevent individuals from taking actions to address steplevel public good collective action problems in particular (Rapoport and Eshed-Levy 1989, Niemiec et al. 2017) because the effectiveness of everyone's contribution is determined by others' contributions (Table 1, row 6).

Although much of the research summarized here has yet to be tested in natural resource field settings, together, it suggests the possibility that different approaches may be needed to motivate land manager action for different types of public good collective action problems (see Table 1, column 4). For example, for continuous collective action problems, increasing an individual's perceived value of the collective good or their personal incentive to contribute to the public good may be crucial. This objective could be achieved through financial incentives or programs seeking to increase environmental literacy or change community norms (Monroe 2003). For step-level public good scenarios, the best focus may be on developing mechanisms for facilitating coordination among individuals to achieve the provision point. For continuous public good scenarios, programs may be more effective by emphasizing the large numbers of others contributing, whereas for step-level goods, programs may instead emphasize how individuals are part of a small group of people, each of whose contribution is critical to achieving the provision point. Although any governance or outreach mechanism for facilitating communication among actors may be effective for step-level goods, the reviewed studies suggest that for continuous public goods, such mechanisms should be face-to-face and/or include binding pledges. Finally, the research suggests that for step-level collective action programs, outreach that assuages individuals' fear that the provision point will not be reached may be particularly important. 


\section{IMPLICATIONS FOR OTHER NATURAL RESOURCE MANAGEMENT CHALLENGES}

We next explore how our logic might apply to understanding two other natural resource management issues on private lands. In particular, we examine how providing habitat for biodiversity conservation and addressing wildfire management risk may create varying degrees and types of public good collective action problems (i.e., step-level and continuous) and what this could mean for optimal outreach and governance approaches.

\section{Habitat provisioning for biodiversity conservation}

The type and degree of public good problem posed by habitat conservation across private lands likely depends on property sizes as well as the characteristics of the species being conserved (e.g., prey base, range, abundance), which influence the vulnerability of its population and the extent and configuration of habitat needed. No collective action problem is created when the management outcome is to enhance native species abundance at a property scale and the property is large enough to provide enough habitat to conserve a species with limited mobility (for instance, as might occur with an endemic plant). A collective action problem is created when there are community-level management objectives for native species conservation or when land managers' ability to help conserve a species is influenced by the efforts of others in the community.

Providing habitat in urban and suburban areas for some native bird (Narango et al. 2017) and bee (Hall et al. 2017) species would both appear to have characteristics of continuous public good problems because research suggests that individual residents can make meaningful improvements to bee and bird habitat without a critical threshold of neighbors being involved (Goddard et al. 2017, Hall et al. 2017). Furthermore, each person's contribution may have a similar effect on bee and bird populations regardless of how many others contribute. Given the continuous public good nature of this scenario, there may be an inherent trade-off between maximizing individual-level benefits and achieving the collective outcome (Table 1, column 2); thus, individuals' value of the collective outcome may be particularly important for determining contributions. Outreach efforts to land managers focused on encouraging bird and bee conservation on private lands may therefore be most effective if they increase the perceived individual or collective value of providing habitat using the strategies discussed in the previous section, demonstrate the large number of others engaging in habitat restoration, and facilitate face-toface communication and binding commitments (Table 1, column 4).

In contrast, creating wildlife corridors can pose a step-level public good if a minimum number of land managers is need to take action to create an effective wildlife corridor, and if, once the corridor is established, additional land manager action would make less of a difference to species survival and abundance. An example of this scenario is the pronghorn migration corridor established on public and private lands in the Greater Yellowstone Ecosystem, which was developed after years of collaborative conservation efforts achieved a critical threshold of land manager support (Berger and Cain 2014).

In some scenarios, the provision point of properties that must be involved may be quite high to achieve biodiversity conservation objectives. For example, just a few land managers of large areas failing to provide habitat for a species may reduce the effectiveness of others' efforts. This situation may occur if there is a small population of an endangered species and land managers are engaging in practices on their property that threaten this small population. For example, if even a small proportion of individuals engages in retaliatory killing of carnivores such as wolves or big cats, or crop-raiding herbivores such as elephants, it can have dramatic consequences for species' survival, particularly if the population is small (Kissui 2008, Swanepoel et al. 2011). Similarly, even small numbers of outdoor domestic cats may have outsized consequences for native bird survival and reproduction through predation and the creation of landscapes of fear (Beckerman et al. 2007). This situation can then reduce the effectiveness of every other land manager's effort to conserve habitat for the vulnerable species on their own properties. In such step-level public good scenarios, outreach and governance approaches may be more effective if they provide mechanisms for facilitating communication and coordination toward the provision point and address individuals' fear that their contributions are not necessary or sufficient for achieving the provision point (Table 1, column 4).

\section{Wildfire management}

The ability of fire to cross large expanses of land means that mitigating fire risk, as well as fostering the beneficial ecological role of fire, poses some level of public good collective action problem. Although there has been implicit recognition of this situation in calls for the comanagement of fire risk, little attention has been paid to the specific context in which collective action is needed and how it might inform outreach and governance approaches. For instance, for the management objective of reducing home losses from wildfires, the degree and type of public good collective action problem posed may vary based on the scale considered, property size, and specific ecological context. Although there currently are insufficient field data to be able to clearly assess whether a particular context represents a step-level or continuous problem, it is still useful to consider how different contexts might lead to different types of collective action problems and hence different outreach approaches, particularly given that outreach programs often take a similar approach regardless of the context.

Studies do provide clear evidence that most homes are lost to ember attack and that appropriate home design and materials and vegetation management around the immediate environs are the critical factors determining structure loss (Maranghides and Mell 2011, Westhaver 2017). Vegetation management generally involves nonflammable materials immediately adjacent to the home (i.e., 1-1.5 m away) and spacing plants and limiting ladder fuels in the area surrounding the home; how far this treatment needs to occur from the home varies by terrain and vegetation type, but the default minimum area tends to be $9 \mathrm{~m}$. Steps to make the actual structure ignition resistant (e.g., fire-resistant roof) have also been shown to be critical. Thus, in areas where homes are on large lots ( $>8 \mathrm{ha})$, reducing the probability of an individual home loss from fire may not pose a significant collective action problem because the likelihood of structural damage can be reduced by individual property manager actions alone, and the effectiveness of actions to manage vegetation is not strongly influenced by the actions of others.

As lots become smaller, however, actions to mitigate fire risk to homes may become more of a collective action problem because 
poorly managed vegetation on adjacent properties could influence risk on one's own property. On more medium-sized lots, reducing risk to a home may still not be a collective action problem, but at the community level, it may be a continuous collective action problem because the more lots that are mitigated, the more limited is the ability for fire to be carried through the community. Also, as property size decreases, nearby homes that are on fire can be a key ember source, increasing the weakness of any home design or vegetation management flaws on one's property. As lots become very small, house-to-house ignition can occur, potentially creating a step-level public good problem at both the individual lot and community levels because even if action has been taken to reduce risk on a few individual lots, this action alone may not be sufficient to prevent ignition from neighboring homes. In this case, as with invasive albizia management, the effectiveness of one's own action is likely influenced by whether a threshold number of neighbors is also taking action (Warziniack et al. 2018). However, research is needed to identify the provision point, or the specific proportion of properties that would need to be ignition resistant for different parcel sizes to reduce the overall risk most effectively for each individual property owner and the community as a whole.

In these scenarios, key findings from collective action research summarized by Abele et al. (2010) and in Table 1 may apply. In the larger lot-size scenario, the focus of outreach may simply need to be on addressing barriers and incentives for each individual property owner. On medium-sized parcels where a continuous collective action problem may be created, coordination may be less important; rather, increasing the perceived value of the collective good to address the inherent trade-off between individual and collective benefits may be crucial (Table 1, column 2). Programs that facilitate face-to-face communication, increase the perceived value of collective and individual outcomes of acting, and highlight how many others are engaging in the action may be effective (Table 1, column 4). Fairbrother et al. (2013) describe a program like this in Australia that brought neighbors together to discuss fire issues and found that it effectively increased resident wildfire preparedness because it led to the creation of valued collective goals and a shared sense of responsibility among neighbors. For areas with very small lots, findings from step-level public good studies may apply (Table 1, column 3). In particular, individuals may be more influenced by the need for coordination and the fear that insufficient numbers of others will contribute to achieve the provision point. In these scenarios, outreach may focus on encouraging individuals to coordinate efforts to ensure the provision point is reached (Warziniack et al. 2018; Table 1, column 4). Such efforts may reduce fear that others will not contribute and increase the perception that efforts on each individual property is critical to achieving the provision point.

The degree and type of collective action that is necessary, and thus the optimal outreach approach, may also depend on the ecological context and what level of land management is required to decrease fire risk to a community for a particular ecosystem. For example, in ponderosa pine (Pinus ponderosa) dominated ecosystems which, when properly managed, tend toward highfrequency but low-intensity fires, residents on larger lots may be able to manage the threat to their homes effectively even if their neighbors do not adequately manage their fuel load. This scenario means that no collective action is needed if the management goal is to mitigate risk to the home. However, maintaining the highfrequency/low-intensity fire system at a community scale would likely require periodic use of prescribed fires. Prescribed fires are most effectively conducted by developing perimeters based on natural features rather than property lines, which would in many cases require burning across a threshold number of properties, potentially creating a step-level collective action problem.

In lodgepole pine (Pinus contorta) dominated ecosystems, where stand replacement (i.e., high intensity) fires are more common, the level of vegetation removal needed to mitigate home risk effectively may not be feasible or desirable on individual properties. Instead, it may be more feasible to create buffers between homes and the forest, such as through cluster developments surrounded by areas with limited fuel. This scenario would also pose a step-level public good problem because most or all residents would need to coordinate efforts to create such a development and buffer area. However, few studies specifically examine how the development patterns that most effectively mitigate fire risk might vary by ecosystem. Therefore, additional studies are needed to clarify how characteristics of the ecosystem may influence the type of fire management collective action problem and what it may mean for optimal outreach and governance approaches.

\section{TOWARD A COLLABORATIVE RESEARCH AND MANAGEMENT AGENDA}

Given the current status of collective action research and practice, we offer a two-step research and management process that could be used to inform optimal outreach and governance strategies for different types and degrees of natural resource management collective action problems. First, we suggest that researchers and managers work together to determine the degree and type of public good problem posed by different natural resource management challenges (such as invasive species management, fire management, habitat conservation) on private lands in a particular social-ecological context. There likely will be a need for research such as the invasive species studies discussed earlier (e.g., Glen et al. 2017) to assess whether the action of multiple land managers is needed to achieve management objectives, and if so, what type of action across properties is needed. For wildfire management, studies may be needed on how specific development patterns may influence the effectiveness of actions to protect homes from wildfire in a specific ecosystem. For habitat provisioning, ecological studies could examine the type and extent of habitat needed to conserve species of concern in different human-dominated landscapes. Findings from these research efforts may be combined with data on property size and configuration in an area to help managers determine whether species conservation poses a step-level or continuous public good problem.

Second, once the degree and type of public good collective action problem is determined, there is a need for field-based social science research to validate the expected differential drivers of decision making identified in lab-based experimental work for continuous, step-level, and nonpublic good collective action problems. Field-based studies are critical to assess the impact of real-world governance and outreach approaches on landowner decision making for different public good collective action 
scenarios. These applied collaborative studies can provide guidance to decision makers on the optimal governance and outreach solutions for each type of problem.

\section{CONCLUSION}

Our essay seeks to move the literature on the social dimensions of natural resource management on private lands toward a more careful consideration of how much and what type of collective action is needed under different social-ecological contexts. There remains a tendency to respond to all cross-boundary natural resource problems with the same strategies, but we argue that more context-specific techniques tailored to the particular type and scope of public good collective action problem may be more effective for achieving desired outcomes. We therefore suggest that scientists and managers engage more deeply with questions regarding the degree and type of public good collective action problem that may be created by a specific management goal and social-ecological context to enable the development of more effective, context-specific policy and outreach solutions for natural resource management challenges on private lands.

\section{Responses to this article can be read online at:}

http://www.ecologyandsociety.org/issues/responses. $\mathrm{php} / 11483$

\section{Acknowledgments:}

This work was supported by a National Science Foundation Decision, Risk, and Management Sciences grant to R. Niemiec (grant 1919353). We thank two anonymous reviewers for their helpful suggestions for this manuscript.

\section{Data Availability Statement:}

Datalcode sharing is not applicable to this article as no new datal code were created or analyzed in this study.

\section{LITERATURE CITED}

Abele, S., G. Stasser, and C. Chartier. 2010. Conflict and coordination in the provision of public goods: a conceptual analysis of continuous and step-level games. Personality and Social Psychology Review 14(4):385-401. https://doi. org/10.1177/1088868310368535

Amel, E., C. Manning, B. Scott, and S. Koger. 2017. Beyond the roots of human inaction: fostering collective effort toward ecosystem conservation. Science 356(6335):275-279. https://doi. org/10.1126/science.aal1931

Aslan, C. E., M. B. Hufford, R. S. Epanchin-Niell, J. D. Port, J. P. Sexton, and T. M. Waring. 2009. Practical challenges in private stewardship of rangeland ecosystems: yellow starthistle control in Sierra Nevadan foothills. Rangeland Ecology and Management 62(1):28-37. https://doi.org/10.2111/07-123

Bagavathiannan, M. V., S. Graham, Z. Ma, J. N. Barney, S. R. Coutts, A. L. Caicedo, R. De Clerck-Floate, N. M. West, L. Blank, A. L. Metcalf, M. Lacoste, C. R. Moreno, J. A. Evans, I. Burke, and H. Beckie. 2019. Considering weed management as a social dilemma bridges individual and collective interests. Nature Plants 5(4):343. https://doi.org/10.1038/s41477-019-0395-y

Bamberg, S., J. Rees, and S. Seebauer. 2015. Collective climate action: determinants of participation intention in communitybased pro-environmental initiatives. Journal of Environmental Psychology 43:155-165. https://doi.org/10.1016/j.jenvp.2015.06.006

Beckerman, A. P., M. Boots, and K. J. Gaston. 2007. Urban bird declines and the fear of cats. Animal Conservation 10(3):320-325. https://doi.org/10.1111/j.1469-1795.2007.00115.x

Berger, J., and S. L. Cain. 2014. Moving beyond science to protect a mammalian migration corridor. Conservation Biology 28 (5):1142-1150. https://doi.org/10.1111/cobi.12327

Brenkert-Smith, H. 2010. Building bridges to fight fire: the role of informal social interactions in six Colorado wildland-urban interface communities. International Journal of Wildland Fire 19 (6):689-697. https://doi.org/10.1071/WF09063

Canadas, M. J., A. Novais, and M. Marques. 2016. Wildfires, forest management and landowners' collective action: a comparative approach at the local level. Land Use Policy 56:179-188. https://doi.org/10.1016/j.landusepol.2016.04.035

Cooke, B., W. T. Langford, A. Gordon, and S. Bekessy. 2012. Social context and the role of collaborative policy making for private land conservation. Journal of Environmental Planning and Management 55(4):469-485. https://doi.org/10.1080/09640568.2011.608549

Cox, M., G. Arnold, and S. Villamayor Tomás. 2010. A review of design principles for community-based natural resource management. Ecology and Society 15(4):38. https://doi. org/10.5751/ES-03704-150438

Doremus, H. 2003. A policy portfolio approach to biodiversity protection on private lands. Environmental Science and Policy 6 (3):217-232. https://doi.org/10.1016/S1462-9011(03)00036-4

Epanchin-Niell, R. S., M. B. Hufford, C. E. Aslan, J. P. Sexton, J. D. Port, and T. M. Waring. 2010. Controlling invasive species in complex social landscapes. Frontiers in Ecology and the Environment 8(4):210-216. https://doi.org/10.1890/090029

Fairbrother, P., M. Tyler, A. Hart, B. Mees, R. Phillips, J. Stratford, and K. Toh. 2013. Creating "community"? Preparing for bushfire in rural Victoria. Rural Sociology 78(2):186-209. https://doi. org/10.1111/ruso.12006

Fenichel, E. P., T. J. Richards, and D. W. Shanafelt. 2014. The control of invasive species on private property with neighbor-toneighbor spillovers. Environmental and Resource Economics 59 (2):231-255. https://doi.org/10.1007/s10640-013-9726-Z

Fischer, A. P., and S. Charnley. 2012. Risk and cooperation: managing hazardous fuel in mixed ownership landscapes. Environmental Management 49(6):1192-1207. https://doi.org/10.1007/ s00267-012-9848-Z

Fischer, A. P., A. Klooster, and L. Cirhigiri. 2019. Crossboundary cooperation for landscape management: collective action and social exchange among individual private forest landowners. Landscape and Urban Planning 188:151-162. https:// doi.org/10.1016/i.landurbplan.2018.02.004 
Fornara, F., P. Pattitoni, M. Mura, and E. Strazzera. 2016. Predicting intention to improve household energy efficiency: the role of value-belief-norm theory, normative and informational influence, and specific attitude. Journal of Environmental Psychology 45:1-10. https://doi.org/10.1016/i.jenvp.2015.11.001

Geiger, N., and J. K. Swim. 2016. Climate of silence: pluralistic ignorance as a barrier to climate change discussion. Journal of Environmental Psychology 47:79-90. https://doi.org/10.1016/j. jenvp.2016.05.002

Glen, A. S., M. C. Latham, D. Anderson, C. Leckie, R. Niemiec, R. P. Pech, and A. E. Byrom. 2017. Landholder participation in regional-scale control of invasive predators: an adaptable landscape model. Biological Invasions 19(1):329-338. https://doi. org/10.1007/s10530-016-1282-3

Goddard, M. A., K. Ikin, and S. B. Lerman. 2017. Ecological and social factors determining the diversity of birds in residential yards and gardens. Pages 371-397 in E. Murgui and M. Hedblom, editor. Ecology and conservation of birds in urban environments. Springer, Cham, Switzerland. https://doi.org/10.1007/978-3-319-43314-1 18

Goldstein, N. J., R. B. Cialdini, and V. Griskevicius. 2008. A room with a viewpoint: using social norms to motivate environmental conservation in hotels. Journal of Consumer Research 35 (3):472-482. https://doi.org/10.1086/586910

Graham, S. 2013. Three cooperative pathways to solving a collective weed management problem. Australasian Journal of Environmental Management 20(2):116-129. https://doi. org/10.1080/14486563.2013.774681

Graham, S., A. L., Metcalf, N. Gill, R. Niemiec, C. Moreno, T. Bach, V. Ikutegbe, L. Hallstrom, Z. Ma, and A. Lubeck. 2019. Opportunities for better use of collective action theory in research and governance for invasive species management. Conservation Biology 33(2):275-287. https://doi.org/10.1111/cobi.13266

Graham, S., and S. Rogers. 2017. How local landholder groups collectively manage weeds in south-eastern Australia. Environmental Management 60(3):396-408. https://doi.org/10.1007/ s00267-017-0859-7

Hall, D. M., G. R. Camilo, R. K. Tonietto, J. Ollerton, K. Ahrné, M. Arduser, J. S. Ascher, K. C. R. Baldock, R. Fowler, G. Frankie, D. Goulson, B. Gunnarsson, M. E. Hanley, J. I. Jackson, G. Langellotto, D. Lowenstein, E. S. Minor, S. M. Philpott, S. G. Potts, M. H. Sirohi, E. M. Spevak, G. N. Stone, and C. G. Threlfall. 2017. The city as a refuge for insect pollinators. Conservation Biology 31(1):24-29. https://doi.org/10.1111/cobi.12840

Hughes, R. F., M. T. Johnson, and A. Uowolo. 2013. The invasive alien tree Falcataria moluccana: its impacts and management. Pages 218-223 in Y. Wu, T. Johnson, S. Sing, S. Raghu, G. Wheeler, P. Pratt, K. Warner, T. Center, J. Goolsby, and R. Reardon, editors. Proceedings of the XIII international symposium on biological control of weeds. U.S. Department of Agriculture, Forest Service, Forest Health Technology Enterprise Team, Washington, D.C., USA. [online] URL: https://www.fs.usda.gov/treesearch/pubs/52706

Isaac, R. M., J. M. Walker, and A. W. Williams. 1994. Group size and the voluntary provision of public goods: experimental evidence utilizing large groups. Journal of Public Economics 54 (1):1-36 https://doi.org/10.1016/0047-2727(94)90068-X
Kelley, H. H., and J. W. Thibaut. 1978. Interpersonal relations: a theory of interdependence. Wiley, New York, New York, USA.

Kerr, N. L. 1989. Illusions of efficacy: the effects of group size on perceived efficacy in social dilemmas. Journal of Experimental Social Psychology 25(4):287-313 https://doi.org/10.1016/0022-1031 (89)90024-3

Kerr, N. L., J. Garst, D. A. Lewandowski, and S. E. Harris. 1997. That still, small voice: commitment to cooperate as an internalized versus a social norm. Personality and Social Psychology Bulletin 23(12):1300-1311. https://doi. org/10.1177/01461672972312007

Kissui, B. M. 2008. Livestock predation by lions, leopards, spotted hyenas, and their vulnerability to retaliatory killing in the Maasai steppe, Tanzania. Animal Conservation 11(5):422-432. https://doi. org/10.1111/j.1469-1795.2008.00199.x

Kollock, P. 1998. Social dilemmas: the anatomy of cooperation. Annual Review of Sociology 24:183-214. https://doi.org/10.1146/ annurev.soc.24.1.183

Ledyard, J. O. 1995. Public goods: a survey of experimental research. Pages 111-194 in J. H. Kagel and A. E. Roth, editors The handbook of experimental economics. Princeton University Press, Princeton, New Jersey, USA.

Lubell, M., S. Zahran, and A. Vedlitz. 2007. Collective action and citizen responses to global warming. Political Behavior 29 (3):391-413. https://doi.org/10.1007/s11109-006-9025-2

Ma, Z., M. Clarke, and S. P. Church. 2018. Insights into individual and cooperative invasive plant management on family forestlands. Land Use Policy 75:682-693. https://doi.org/10.1016/j. landusepol.2018.02.010

Maranghides, A., and W. Mell. 2011. Case study of a community affected by the witch and guejito wildland fires. Fire Technology 47:379-420. https://doi.org/10.1007/s10694-010-0164-y

Marshall, G. R., M. J. Coleman, B. M. Sindel, I. J. Reeve, and P. J. Berney. 2016. Collective action in invasive species control, and prospects for community-based governance: the case of serrated tussock (Nassella trichotoma) in New South Wales, Australia. Land Use Policy 56:100-111. https://doi.org/10.1016/j. landusepol.2016.04.028

McCaffrey, S. 2015. Community wildfire preparedness: a global state-of-the-knowledge summary of social science research. Current Forestry Reports 1(2):81-90. https://doi.org/10.1007/ $\underline{\mathrm{s} 40725-015-0015-7}$

McKiernan, S. 2018. Managing invasive plants in a rural-amenity landscape: the role of social capital and Landcare. Journal of Environmental Planning and Management 61(8):1419-1437. https://doi.org/10.1080/09640568.2017.1351930

Meinzen-Dick, R., M. DiGregorio, and N. McCarthy. 2004. Methods for studying collective action in rural development. Agricultural Systems 82(3):197-214. https://doi.org/10.1016/j. agsy.2004.07.006

Monroe, M. C. 2003. Two avenues for encouraging conservation behaviors. Human Ecology Review 10(2):113-125 
Narango, D. L., D. W. Tallamy, and P. P. Marra. 2017. Native plants improve breeding and foraging habitat for an insectivorous bird. Biological Conservation 213(A):42-50. https://doi. org/10.1016/j.biocon.2017.06.029

Niemiec, R. M., N. M. Ardoin, F. K. Brewer, S. Kung, and K. Lopez. 2018. Increased neighbor interaction and fear of social sanctions: associations with resident action to control the invasive little fire ant. Society and Natural Resources 31(10):1149-1168. https://doi.org/10.1080/08941920.2018.1456594

Niemiec, R. M., N. M. Ardoin, C. B. Wharton, and G. P. Asner. 2016. Motivating residents to combat invasive species on private lands: social norms and community reciprocity. Ecology and Society 21(2):30. https://doi.org/10.5751/ES-08362-210230

Niemiec, R. M., R. P. Pech, G. L. Norbury, and A. E. Byrom. 2017. Landowners' perspectives on coordinated, landscape-level invasive species control: the role of social and ecological context. Environmental Management 59(3):477-489. https://doi.org/10.1007/ $\underline{\mathrm{s} 00267-016-0807-\mathrm{y}}$

Niemiec, R. M., R. Willer, N. M. Ardoin, and F. K. Brewer. 2019. Motivating land managers to recruit neighbors for private land conservation. Conservation Biology 33(4):930-941. https://doi. org/10.1111/cobi.13294

Ostrom, E. 1990. Governing the commons: the evolution of institutions for collective action. Cambridge University Press, Cambridge, UK.

Prokopy, L. S., K. Floress, D. Klotthor-Weinkauf, and A. Baumgart-Getz. 2008. Determinants of agricultural best management practice adoption: evidence from the literature. Journal of Soil and Water Conservation 63(5):300-311. https://doi. org/10.2489/jswc.63.5.300

Rapoport, A., and D. Eshed-Levy. 1989. Provision of step-level public goods: effects of greed and fear of being gypped. Organizational Behavior and Human Decision Processes 44 (3):325-344.

Swanepoel, L. H., P. Lindsey, M. J. Somers, W. Van Hoven, and F. Dalerum. 2011. The relative importance of trophy harvest and retaliatory killing of large carnivores: South African leopards as a case study. South African Journal of Wildlife Research 44 (2):115-134. https://doi.org/10.3957/056.044.0210

Vanderwoude, C., K. Onuma, and N. Reimer. 2010. Eradicating Wasmannia auropunctata (Hymenoptera: Formicidae) from Maui, Hawaii: the use of combination treatments to control an arboreal invasive ant. Proceedings of the Hawaiian Entomological Society 42:23-31.

Warziniack, T., P. Champ, J. Meldrum, H. Brenkert-Smith, C. M. Barth, and L. C. Falk. 2018. Responding to risky neighbors: testing for spatial spillover effects for defensible space in a fireprone WUI community. Environmental and Resource Economics 73:1023-1047. https://doi.org/10.1007/s10640-018-0286-0

Westhaver, A. 2017. Why some homes survived: learning from the Fort McMurray wildlandlurban interface fire disaster. ICLR research paper series 56. Institute for Catastrophic Loss Reduction, Toronto, Canada. [online] URL: https://www.iclr.org/
wp-content/uploads/PDFS/why-some-homes-survived-learning-fromthe-fort-mcmurray-wildland-urban-interface-fire-disaster.pdf

Yung, L., J. Chandler, and M. Haverhals. 2015. Effective weed management, collective action, and landownership change in western Montana. Invasive Plant Science and Management 8 (2):193-202. https://doi.org/10.1614/IPSM-D-14-00059.1 